\title{
A Study of a Variation in Cleavage.
}

\author{
By \\ T. H. Morgan. \\ With plate $\mathrm{X}$. \\ Eingegangen am 21. Februar 1895.
}

If the eggs of Sphaerechinus be gently shaken in a small tube from two to five minutes after fertilization the outer membrane is removed, as Driesch has shown, from many of the eggs. If the eggs are shaken violently each is drawn out into a long filiament. The following account applies only to those eggs that have been gently shaken at the time given above. They have, therefore, not had their outlines altered to any extent.

Most of these eggs segment normally dividing into 2, 4, 8, and 16 blastomeres. Some of the eggs however divide at once into three equal parts as shown in Fig. $1 \mathrm{~A}, \mathrm{~B}$, the division takes place synchronously with the normal cleavage. I have measured many of these eggs at the time of division and find, as the figures show, that the long axis of each blastomere is in the direction of the planes of division of the first eleavage, or in other words, the long axis of each blastomere is parallel to the line of intersection of the planes separating the blastomeres. It will be convenient to call the first division-planes the vertical planes and orient the other planes correspondingly. Camera drawings of the living eggs confirm completely the results of actual measurements of the eggs. Further if the eggs are killed in a dilute solution of Formol one can repeat at leisure the measurements. Formol kills the eggs at once without causing any apparent change in the outlines of the cells.

During the resting stage the long axis of each blastomere shortens somewhat as the blastomeres press together, Fig. $2 \mathrm{~A} \mathrm{~B}$, but even then the vertical axis of each cell remains longer than any other axis until just before the time of the second 
cleavage. Each of the three blastomeres then divides into two equal parts. The planes of division are also vertical, as Fig. 4 shows. In other words the division has taken place in what was the long axis of each blastomere.

If the blastomeres be measured $\mathrm{j} u \mathrm{st}$ before the second division planes appear, Fig. $3 \mathrm{~A} \mathrm{~B}$, it will be found that as the spindles form for the second division the blastomeres lengthen, so that before the division actually takes place each cell has its long axis in the direction of the forming spindles. The important point is that the change does not take place until the cell begins to divide.

In nearly all cases the six cells that have been thus formed lie in one plane and form a circle. The cells do not meet at the centre of the ring so that an opening is present (Fig. 4). Occasionally one or (oftener) two of the six blastomeres shifts above (or below) the plane of the others and often a part of one blastomere may slightly overlap (above or below) its neighbor. The circle of cells may be either radial or bilateral in its arrangement.

The third cleavage planes are at right angles to the preceeding planes i. e. they are "horizontal . Usually each of the six cells divides into two unequal parts, so that a circle of six smaller cells rests on a circle of six larger cells, Fig. 5 A B. There is some variation in different eggrs in regard to the inequality in size of the two circles of cells, and also some variation in the division of individual blastomeres. When the symmetry of the six cell-stage was disturbed, the twelve cell-stage will also vary.

At the fourth division, Fig. 6, each of the twelve blastomeres divides. The planes of division are again »horizontal or nearly so (oblique). The circle of six larger cells divides into twelve cells of equal size, while the upper circle of six smaller cells divides, forming six quite small cells, the micromeres, and six larger cells. We have then as a result four circles of cells, each circle containing six cells. During division the cells may shift somewhat so that the arrangement may be here and there irregular:

I have made a study of the sizes of the six micromeres of these eggs and compared them with the sizes of the four micromeres of the normal eggs. Reference to the figures (Fig. 5, 6, 7, $8,9)$ will make a description scarcely necessary. It will be seen that any one of the six micromeres is smaller than any one of the four micromeres of the normal eggs. But the sum total of 
the volumes of the six is.greater than the volumes of the four.

I isolated ten of those eggs which had divided at once into three to see whether normal embryos developed from them.

Friday Morning

Sat. Aft.

Sund.

Mond.

\begin{tabular}{|c|c|c|c|}
\hline $1 \mathrm{Egg}$ & $\begin{array}{l}\text { Gastrulated } 1 / 2 \text { archen- } \\
\text { teron) }\end{array}$ & Finished gastrulation & $\begin{array}{l}\text { Later no ske- } \\
\text { leton or arms } \\
\text { developed }\end{array}$ \\
\hline- & $\begin{array}{l}\text { Begun to gastrulate } \\
\text { Not gastrulated } \\
\text { Begun to gastrulate }\end{array}$ & $\begin{array}{l}\text { No further } \\
\text { Not gastrnlated } \\
\text { Imperfect gastrula }\end{array}$ & \\
\hline & & $\left\{\begin{array}{l}2 \text { perfect gastrulae } \\
1 \text { gastrulated } 1 / 4 \text { Archen }\end{array}\right.$ & $\begin{array}{l}2 \text { Finished } \\
\text { gastrulation }\end{array}$ \\
\hline - & & $\left\{\begin{array}{cccc}1 & - & 1 / 2 & - \\
1 & \text { Abnormal } & 1 / 2 & - \\
1 & - & 1 / 2 & -\end{array}\right.$ & $\left\{\begin{array}{l}2 \text { not finished } \\
2 \text { did not gastrn- } \\
\text { late. }\end{array}\right.$ \\
\hline
\end{tabular}

It is not uncommon to find amongst eggs artificially fertilized, that a few egg's divide at once into four equal parts. DrIesch has observed these and has recorded that when he isolated such eggs not one went further than the blastula stage. He thought that the division into four was due to polyspermy, but has made no direct observations to support the hypothesis.

In those eggs that have divided at once into three we must assume that three archoplasmic centers are present. It is useless to speculate on the origin of these centers without having any oliservations to go upon. A careful study of the number of chromatin rods, in the triangular karyokinetic figure at the time of the threefold cleavage, ought to show at least whether we have here a case of polyspermy. Although I have studied many preparations made to determine this point I have not yet reached any definite conclusion.

If we compare the methods of division of the normal and three-fold cleavages, we find that in both the second planes of cleavage are "vertical«. This may give us a clue as to the reason why the cells of the three-fold cleavage divide by "vertical "rather than by $\gg$ horizontal planes at the second cleavage. In the normal two cell-stage the centres for the next division place themselves on opposite sides of the nuclei. The line that joins each two centers is at right angles to the long axis of the first spindle, and also so placed that the next division-plane will halve the micromere field of each blastomere. Now the same thing happeus in the three-fold 
type when it divides -into six cells. The centers here also must place themselves on opposite sides of each nucleus, and again the line that joins each of the two centers is at right angles to the path of previous movement of the chromatin and also placed in relation to the micromere field of each blastomere.

Hen'Tig has enunciated the general statement that the karyokinetic spindle of a cell places itself in the direction of the greatest protoplasmic mass. Pfü̈GER had made previously a nearly similar statement. In the case of the three-fold cleavage we find that this statement, sometimes called HenTwig's law, does not hold. In all cases it seems to me we must rather look to the positions which the archoplasmic centers take before division and it has not been shown by any means that in all cases these are regulated by the mass of protoplasm.

A further observation in respect to the three-fold type of cleavage should be here recorded. In the shaken eggs many divided at once into three parts, but very few or none divided at once into four parts. In the unshaken eggs of the same female on the contrary a number divided at once into four and not one, in this lot, was found to divide into three parts although many thousands of eggs were examined. I have however very rarely found an egg in an unshaken lot that had gone at once into three equal parts. The reason for this difference $I$ do not know. If we assume polyspermy in both cases, $I$ see even then no explanation of the fact that there should be three centers of attraction present under certain conditions and generally four under other conditions. A study of preserved preparations of eggs dividing at once into three and four equal parts shows in the one case three archoplasmic centres and in the other case four centres. If the normal number of chromosomes is eleven for each pronucleus, the normal segmentation nucleus should contain twentytwo chromosomes, and when these have divided and have begun to migrate to the poles, there will be forty-four in all. If the eggs have been doubly fertilized there will be thirty-three chromosomes in the segmentation nucleus, which when divided will give sixty-six. It is of course extremely difficult to count accurately such large numbers of ehromosomes. In one egg dividing into four I counted 40 chromosomes, in another 64 , and in another 62 . In the first egg all of the chromosomes may not have yet divided so that the second and third estimates are of more value. I cannot 
give much weight to these results however, but so far as they go they point to dispermy.

The preparations show another result of much more importance. There is always an unequal division of the number of chromosomes present, both in the three-fold and in the fourfold types. Towards some of the centres are drawn more chromosomes than towards others. In one case for instance of four-fold cleavage, one centre got 17 chromosomes, another 14, another 33 and one centre got none at all.

We can understand then why such eggs do not produce normal larvae, for the resulting cells will contain very different numbers of chromosomes, and the chances are that none of them will contain the normal number.

Further we see why the eggs which have divided into three. do sometimes produce gastrulae and young larvae while those that divide at once into four never produce gastrulae (according to DrIEsch); for the ehances of a more equal division of the chromosomes is greater in atriaster than in a tetraster. This is shown by direct observation of dividing eggs and is also true on the theory of probability.

Turning now to the formation of the six micromeres we see that they are directly the result of the first division of the egg into three parts instead of into two. The micromere field must be present in the egg prior to the first cleavage. This micromere field is divided into two parts if the egg, as normally, divides into two parts, and into three parts if the egg is divided into three. Each blastomere therefore has at one end some of the micromere protoplasm. This protoplasm in each cell must be again divided so that in the fourcell stage there will be four regions of micromere-protoplasm, or in the three fold cleavage six such regions. When that stage of the cleavage is reached at which the micromere-protoplasm is separated from those cells that contain it, there will be formed four micromeres in the one case, and six in the other. That this is the real interpretation of the phenomenon can not be doubted. when we take into account the parallel results that DRIEscr obtained. from the eggs of Sphaerechinus and Echinus.

DRIESCH has described in the »Entwicklungsmechanische Studien « No. V under the title "Von der Furchung doppelt befruchteter Eier « certain unusual methods of cleavage of Echinoderm eggs when subjected to a temperature higher than normal. The title of the 
paper is so far misleading, as DRIEscr says, in that he has never observed directly that two spermatozoa enter. He infers that they must from a comparison with the results of Fon and the HeRTwigs with doubly fertilized egg, and from his own observation that such eggs do not go far in development. Driesch observed further that these eggs divided into four parts in the same time that the normal eggs divide into two.

There are two types of tlese four-celled stages. In one type the four blastomeres are produced by four »vertical " planes in the same sense that the three-fold type is produced by three vertical planes. The four cells lie in a circle with a central opening. In the other type the egg divides producing four blastomeres which are arranged from the beginning in a tetrahedron, Fig. 10.

In the first type - $>$ circular form" - the second cleavage comes in also vertically giving a circle of eight cells in one plane. DRIESCH interprets this as a double eight-cell stage. He says: "Der Rhythmus der ganzen Theilung ist also in strengster Weise doppelt aufgetreten: das 16-Stadium der zweifach befruchteten Eier ist also nicht das 16-Stadium der normalen Furchung (mit vier Mikromeren), sondern es ist das Doppelte ihres 8-Stadium. «

The third cleavage is "horizontal" $i$. e. at right angles to the preceding and there results two circles, each circle of eight cells.

At the next division eight micromeres are formed from the cells of one circle, and the eight cells of the other circle divide each into halves, Fig. 12.

This $32-c e l l$ stage of the four-fold cleavage is directly comparable with the 24-cell stage of the three-fold cleavage described above.

Turning now to the other type of four-fold cleavage in which the four cells constrict off in the form of a tetrahedron, Fig. 10, we find that each of the four cells divides equally into two at the next division, and each of the two again into four equal cells (Fig. 11). We can speak of the descendents of each of the first four as a »packet $\ll$. , Was nun die Bildung des Doppelsechzehn-Stadiums bei unseren Objekten angeht, so sollte man erwarten, dass von jedem der vier vierzelligen Packete zwei Zellen sich zu gleichen Theilen furchten, während die beiden anderen Mikromeren abschnüren würden; es wäre dann, abgesehen von der Lagerung, doch nach Zahl und Art der Zellen der Typus der normalen Doppelfurchung gewahrt 
Dies ist aber nicht der Fall; so weit meine ziemlich zahlreichen Beobachtungen reichen, bildet kein tetraedrisehes objekt acht Mikromeren, sondern vier oder sechs, und zwar möchte ich den Thatbestand in folgenden Satz zusammenfassen:

Von den Zellen jedes der vier Packete sind zwei befähigt Mikromeren zu bilden; sie thun es (eine oder beide) nur dann, wenn es vermöge der Lageordnung möglich ist, dass ihre Mikromeren sich mit den von den anderen Packeten gebildeten zusammenlagern können; nie liegen Mikromeren an differenten Stellen. «

»Mit dem Satze: bei der Furchung doppelt befruchteter Eier tritt jede Zellenkategorie doppelt auf, sofern nicht Einfliisse der Lage störend eingreifen, beschließe ich die Darstellung dieser Furcherscheinungen. ....

The cause of the formation of the micromeres can not lie, I think, in the relative positions of the cells. Nothing moreover is gained by calling the four-fold cleavage a »double cleavage", because the doubleness of the clearage fails to show itself in the tetrahedral type, as Driesch shows. I refer of course to the formation of the micromeres. Further if the fourfold type is a double cleavage, what shall we call the three-fold cleavage? It would be a one and a half cleavage!

Moreover the results that Driesch has gotten for the tetrahedral four-fold cleavage shows, it seems to me, in the clearest way that a micromere field must be present in the egg prior to division! It will be seen at a glance, Fig. 10, that if such a region were present in the tetrahedral form at or near the surface it could be divided at most only amongst two or three of the blastomeres. The arrangement of the four cells into a tetrahedron is not due to a reshifting of the blastomeres after clearage, but the four masses (blastomeres) pinch off arranged in that form. Consequently the two or three cells containing micromere protoplasm will at their next division again divide that protoplasm, so that four or six cells will get part of the same. Conseruently when the time comes for the formation of the micromeres we get only four or six of these cells. We see further why these cells are always found near to one another, for the micromere protoplasm must have kept throughout its subsequent divisions near that region where it first existed.

In the summer of $1893 \mathrm{I}$ found 1 that as early as the two cell

1. Anatomischer Anzeiger Bd. IX, Nr. 5-6: 
stage in Arbacia the micromere pole is foreshadowed owing to the migration of pigment grannles from one region of the egg. The present results show that this polar differentiation must be present even prior to the first division.

In a short report in the Anatomischer Anzeiger Bd. X, No. 1, Dec. 1, 94 of a paper read by Wilson before the New York Academy of Sciences it is stated, »that the definitive egg-axis has no constant relation to that [axis] passing through the excentric eggnucleas, but may form any angle with it. The first cleavage passes approximately through the point of entrance of the spermatozoon as described by Rovx in the frog «. This result for the Echinoderm eggs supports, rather than weakens, the position taken above, for since the first cleavage plane goes approximate through the entering point of the spermatozoon, and the centre of the egg, but bears no constant relation to the excentric egg nucleus, the plane may therefore pass through any point in the surface of the spherical egg, and therefore halve or divide into three the micromere field if present. It will be better however before speculating further to wait for the full report of WrLson's work. I may repeat however here that my own results combined with those of Driescir's demonstrate only that just prior to division the micromere field must be present in the egg and it is possible that this differentiation may only take place after the entrance of the spermatozoon into the egg.

Barfurth $^{1}$ ) has, on the evidence of my observation on the eggs of Arbacia ranked me amongst those who. hare spoken in favor of an $»$ Organbildende Keimbezirke of the egg. It may be well to point out that those results, and these new resalts also, have nothing whatsoever to do with Organbildenden Keimbezirke. The results go to show, if I mistake not, that even prior to division (perhaps only after fertilization) the protoplasm of the ego is not all alike so that a region of special protoplasm, which later goes into the micromeres, is set aside at an early period. But this is not an Organbildenden Keimbezirke in His' sense! The first cleavage of an egg may bear some definite relation to the presence of yolk in certain parts of the egg, but because we can see the yolk there before clearage, it does not follow there exists in such an egg preformed foundations ("Anlagen «) of the later organs.

Neither Barfurth nor any one else has shown that the micromeres

1. Ergebnisse der Anatomie und Entwickelnngsgeschichte. III. Band. 1893. 
themselves form any definite organs of the larva. On the contrary DRIESCH's experiment of isolation of portions of the segmented egg not containing micromeres, go to show that the micromeres are undifferentiated blastomeres and are not set aside to form any special organs, because normal embryos still come from such fragments without micromeres.

\section{Zusammenfassung,}

Geschiittelte Seeigeleier theilen sich bisweilen in 3 Theile, die zweite Theilungsebene geht dann durch die Längsachse jeder Zelle, in Widerspruch mit 0 . HerTwig's $\triangleright$ Gesetz .

6 Mikromeren werden von solchen Eiern gebildet. Diese Thatsache zeigt, in Verbindung mit ähnlichen Resultaten, welche DrIesch an simultan viergetheilten Eiern erzielte, dass eine protoplasmatische Mikromerenregion bereits. vor der ersten Furchung am Ei vorhanden sein muss.

Die Gesammtsumme der Volumina der 6 Mikromeren ist größer, als die Summe der Volumina der normalen 4 Mikromeren, aber jede der 6 Mikromeren ist doch kleiner als jede der 4 .

Der Grund dafür, dass ans dreifach nnd vierfach gefurchten Eiern gewöhnlich keine normale Gastrula entsteht, liegt in ungleicher Vertheilung der Chromosomen bei der ersten Furchung.

\section{Description of Plate $X$.}

Fig. 1 A. B. Three-fold cleavage. Egg. has just divided. Camera 3 C. Zeiss.

Fig. 2 A. B. Three-fold cleavage about one half hour after division. Camera $3 \mathrm{C}$.

Fig. $3 \mathrm{~A}$. B. Three-fold cleavage. The sspindles * for the next cleavage are forming. Camera $3 \mathrm{C}$.

Fig. 4. The second cleavage has formed in the three fold type 6 cell-stage). Camera $3 \mathrm{C}$.

Fig. 5 A. B. After the third cleavage (12 cell stage).

Fig. 6. After the fourth cleavage (24 cell stage). $3 \mathrm{C}$.

Fig. 7. A group of six micromeres of the 24 eell stage. $3 \mathrm{C}$.

Fig. 8. A group of six micromeres in process of forming at the 24 cell stage. $3 \mathrm{C}$.

Fig. 9 A. B. A normal 16 cell stage drawn to same scale as Fig. 6.3 C.

Fig. 10. Four-fold cleavage of tetrahedral type. (Copied from DrIEsch.)

Fig. 11. Sixteen cell stage of tetrahedral type. (Copied from DrIEsch.; The letters indicate the cells descended from the same blastomere. The four erosses in cells $a, b, c, d$ indicate the point where the 4 mieromeres appeared.

Fig. 12. Thirty-two cell stage with eight micromeres (copied from DrIEsch). From the fovi-fold radial (or circular) type of cleavage. 